\title{
REVIVING THE THRACIAN HERITAGE AT THE BEGLIKTASH SANCTUARY: ADMIRED, PROBLEMED, REAL
}

\author{
Diana Radoynova \\ University "Prof. d-r Asen Zlatarov", Burgas, Bulgaria \\ diana_radojnova@abv.bg
}

\begin{abstract}
The article presents one of the most interesting archaeological sites in the Burgas region - the Thracian sanctuary Begliktash near the town of Primorsko. It was discovered by archaeologists only in the early 21 st century. An attempt was made to trace his short journey from complete obscurity to a popular tourist destination, a scene of various attractions and local cultural value. Tourist visits undoubtedly enliven the Thracian sanctuary. The issue is whether each attraction turns it into a "living cultural heritage".
\end{abstract}

Keywords: Thracian Sanctuary Begliktash; Revitalizing; Living Cultural Heritage.

\section{СВЕТИАИЩЕТО БЕГАИКТАШ: ААМИРИРАНО, ПРОБАЕМНО, РЕААНО}

\author{
Аиана РаАойнова
}

Университет „Профр. А-р Асен ЗАатаров“-Бургас, България

Резюме: Статията преАставя еАин от най-интересните археологически обекти в Бургаска област - тракийското светилище Бегликташ край граА Приморско. Открит е от археолозите еАва в началото на 21 век. Направен е опит $а$ а се проследи краткото му пьтуване от пьлна неизвестност Ао популярна туристическа Аестинация, сцена с размични атракции и местна културна ценност. Туристическите посещения несьмнено оживяват тракийското светилище. Въпросът е Аали всяка атракция го преврьща в "живо културно наслеАство“.

КАючови Ауми: Тракийско светилище Бегликташ, оживяване, живо културно наслеАство

Тракийското светилище на 3 км. от Приморско е функционирало без прекъсване близо 2000 голини - от XV век пр. Хр. Ао IV в. с^. Хр. СлеА това, порали залеза на сакралността, която олицетворява, то заспива за почти още толкова време. През османския периол е известно на местните хора пол името Бегликташ - камъкьт, 
където се плащал бегликът - Аанъкът за сталата. И извеАнъж, в началото на XX век, неговата слава изгрява с нова сила.

Maкар $\Delta$ а е споменат в края на XIX в. от братя Шкорпи^ (Chkorpil et al., 1913: р. 241), скалният комп^екс бива преоткрит от българската археологическа и траколожка наука еАва почти век по-къСНо (ИзслеАван е и бегло описан от екипа на експедиция „Аполония-Странджа“), (Fol (ed.), 1982: р. 348), (Fol (ed.), 1976). Реално неговият откривате^ за света и науката става екип пол ръководството на Аиректора на РИМ-Бургас, $\Delta-\mathrm{p}$ Цоня Аражева през 2002 г. За три голини археолозите успяват Аа свършат много работа и най-важното - $а$ а $\Delta$ аАат публичност както на труда си, така и на обекта.

Аревността на комплекса е впечатляваща - артеорактите (керамика, монети, животински кости) - Аават основание $а$ а се твърди, че тук е имало непрекъснато културно присъствие от $\vee I I-\vee$ век пр. Хр. Ао IV век с^. Хр. (Marazov and Chalganova, 2005: pр. 482-485). Скалните форми носят слеАи от частична изкуствена обработка и специално полрежлане, но доминира „приролният реА“. СпореА изслеАователите за „законите на митологичното мислене всеки културен акт трябва $а$ а изглежАа пределно „естествен“, за да се повиши степента на неговата Аегитимност... Защото по този начин „природното“ се отъжАествява с „божественото“и съответно придобива по-висок семиотичен статус в йерархията на сакралното" (Marazov and Chalganova, 2005: р. 485).

В плоските хоризонтални скали се прелполага, че са изсечени каменни крьгове, вА^ъбнатини и стьпки. Намерени са и останки от жилищна сграда и култови огнища. Най-впечатляващият елемент от комплекса е ансамбъльт от четири огромни менхири, разположени по много специдричен начин, както и внушителен Аолмен. Елементите на целия комплекс са разположени по оста изток-запаА. Фрагментите от комплекса с убелително култово преАназначение са:

○ Т. нар. "Брачно ложе“ - каменно „легло“ С „възглавници", ориентирани на изток. Аопуска се, че на него се е възпроизвеждала от жреци хиерогамията межАу Великата Богиня-майка и нейния соларен съпруг. СпореА някои изслеАователи е възможно товяа също така да се е осмисляло и като граманна трапеза 
- Жертвеник, върху чиято монолитна основа са изАълбани ямки, в които вероятно са били принасяни като жертва смятаните за свещени от траките течности - вода, вино, мАяко и зехтин.

- "Трон", за който се предполага, че е бил заеман от Върховния жрец по време на ритуалите. Каменната селалка на трона е била закрепена върху еАна от големите скали, но вероятно от тектонични трусове е съборена на земята.

- СърцевиАният камък, който още Шкорпил Аокументира поА името Апостол Таш - огромна скала, която има сърцевинна орорма и лежи на плоската скала пол нея, опирайки се само в три точки. Межлу Авете скали се оорормя ниша, в която може $а$ а се побере само легнала човешка фоигура. Археолозите установяват, че около 22 юни, по времето на мятното сльнцестоене, през нишата като сноп преминават сльнчевите ^ъчи, което Аава основание $а$ а се мисли, че този елемент от скалния комплекс е своеобразна астрономическа наблюАателница.

- Това твърдение се Аопълва и от наличието на т. нар. от съвременните изследователи Сльнчев часовник - мегалитен ансамбъл от шест плоски камъка, разположени северно от Апостол Таш, като сянката на Апостол таш пала върху различен камък в различните части на Аеня.

- Т.нар. "Аабиринт" - композиция От скални монолити в североизточната част на светилището. Аопуска се, че е би^ част от орорическата обелност. Посветеният трябвало $\Delta а$ влезе през левия вхо А И, воАен от сакралната сила, Аа намери пътя Към Аесния изхол, като фриналното изпитание било $а$ се премине през изключително тесен процеп (около 30 см.), изкуствено издълбан в огромен скален къС С височина наА $6 \mathrm{M}$.

- "Аоммен" - това е еАна от най-големите подобни каменни фороми на Балканите. Намира се в югоизточната част на комплекса непосредствено слеА Аабиринта. ГлеАан фрронтално, напомня силует на легнала жена с разтворени, свити в коленете крака. Познавачи на тракийския орфизъм смятат, че вероятно посветеният е трябвало Аа извърви пътя на пречистването: от хиерогамията на 
божествата, през лабиринта и като фоинал $\Delta а$ се появи преА мистите през отвора на Аолмена. Прехольт символизирал преминаването от време към безвремие, от нечисто към чисто, от тьмнина към светлина, от профранно към сакрално. На няколко места в плоските скали има фрорми, наподобяващи стьпки, които биха могли да символизират, че пьтят му минава по слеАите на божественото' .

Прелполага се, че Бегликташ е сакрален култов топос на скирмианите, тракийски племенни общности, населявали този район на СтранАжа. Целият скален комплекс може $а$ се тълкува като петроглиф на универсалния молел на тракийския орфизъм, свързан с почитането на Великата Богиня Майка-Земя и нейния син-съпруг С^ьнце/Загрей/Аионис. Той свилетелства за силната вяра, техническите умения и астрономическите знания на траките, както и за продьлжително общостно усилие за полдьржане на сакрално пространство.

В голините слеА разкриването на скалното светилище Бегликташ съм имала възможност многократно $а$ а се заврьщам на този терен. Теренната информация може да бъле оцелостена с оглеА целите на настоящия текст - опционално пресичане на наследени културни присьствия у нас, концепции за оживяването им и Аигиталното форсиране на инорормацията за тях и илеи за комерсиалната им експ^оатация. Би би^о ползотворно съпоставянето и анализирането на множеството "моментни снимки" на терена, реализирани и анализирани с антроположки метолики, както и на набъбването на Аигиталния масив от инорормация за него.

2006. Обектьт е почти пуст. Ао него се стига слеА отк^онение от главното шосе по коларски пьт, осеян с трапове и напаАали клони. Изпод еАно Аьрво От Горичката преА скалния Масив Изскача м^аАО

1 Интерпретацията на отАелните Аетайли, устойчиво присъстващи в почти всички тракийски скални светилища, е Аетайлно представена от (Chalganova, 2012: pp. 161192).

REVIVING THE THRACIAN HERITAGE AT THE BEGLIKTASH SANCTUARY: 
момиче, което продава билети „за вхол“. Неуверено казва, че билетите вкАючват и екскурзоволска бесела. Беселата е съвсем кратка и като за пь^Ни ^аици.

Придружаващият ни учен - профресор на няколко пьти поправя терминологични грешки. Момичето се отказва да "беселва" и ни преАлага самостоятелно Аа разгледаме комп^екса. През цялото време няма жива душа. Абсолютно незабележим е Бегликташ и в Аигиталния свят: няма Аинкове Към галерии със снимки, няма инорормационни статии, няма рек^амни портали. Само кратки публикации на блогъри от типа „бях на еАно страхотно И никому неизвестно място“. АОкументално съществуват еАинствено археологическите и културологичните хипотези на учените, публикувани като сьобщения в няколко местни и национаАни медии.

2013. Заглавие в местен инорормационен сайт "Зрелищен спектакъл на багатури в Бегликташ". Публикацията съобщава, че клуб „Багатур“ ще разиграе на мястото зрелищни битки, възпроизвежлащи различни старинни бойни техники, като представлението е в полкрепа на кандилатурата на Бургас за Европейска столица на културата през 2019г. (petminuti.com/зрелищен-спектакъл-на-багатури-в-бегликташ/).

„Битките" са Аоста нагласени и муАни, а Аемонстрираните бойни техники - направо отчайващи. Организацията на мероприятието е с куп неуредици, които отказват много хора, още прели да са стигнали Ао светилището. Публикациите на няколкото инорормационни агенции, популяризиращи мероприятието, в интернет-пространството са последвани от неприязнени, саркастични или направо груби коментари.

2016. Бургаски инорормационен сайт транслира инорормация за инициатива на Община Приморско: „Този уикенА Приморско отново ще се върне във времето с пресъздаването на древен тракийски ритуал. ХиляАолетни традиции ще оживят тракийското светилище Бегликташ. То ще се възроди за церемонии, Аароприношения и обреди, така, както са ги извьршвали преАците ни ...Инициативата е на общината, която кани всички желаещи $ы$ се телепортират във времената на жреци, божества и магични сили на ритуали..." 
(viapontika.com/index.php?page=article=20947). В същата година (25.08.2016) бургаското приложение на националния ежедневник, в. ТруА, излиза на електронната си страница сьс статия пол заглавие "Извънземна си^а пази древното светилище Бегликташ“. Статията разказва, че „необяснима извънземна енергия пази мистичните мегалити на Аревното светилище Бегликташ край Приморско... Радиестезистите са категорични, че измерванията на мястото показват, че там се крьстосват мощни космически сили, които карат махалата им да полудяват..." Цитиран е профр. Стамен Стаменов, уфролог, който твърАи, че „преАи хиляди години светилището е било космическа база на извьнземните" и че "и Ао Анес Бегликташ е база на няколко извьнземни цивилизации с много висок ранг на развитие". Авторите на статията Аават собствена интерпретация на археологическите наличности: „Бегликташ сбъдва всякакви желания... Светилището е еАин от комуникационните центрове с Космоса... ^абиринтьт е служел за предсказване на бъдещето и занятието, към което ще се насочат м^алежите от племето. Тези, които най-бързо успявали $\Delta а$ излязат от ^абиринта, се славели в племето като носещи специална силна енергия, която им помага в битките" (trud.bg/ извънземна-си^а-пазиАревното-светилище/).

2017. Покана в интернет-пространството от регионално бургаско ралио: „Аревен тракийски ритуал ще бъле пресъзАален на светилището Бегликташ край Приморско. Посетителите на вьзстановката ще се пренесат вьв времената, когато самодиви и божества са бракосьчетавали Богинята-майка и Бога-сльнце... Ритуалите ще бъдат осъществени чрез течности, смятани в Аревността за свещени. Тогава виното е представлявало земята, зехтиньт - огъня, м^якото - възАуха, а водата си е би^а во Аа" (dariknews. bg/regioni/burgas / vizhte-dreven-trakijski-ritual-na-begliktash -2033641).

2018. В Интернет е отправена покана за участие в пречистващ тракийски ритуал „поА ръководството на Ралананда, Ауховен учител”. Мероприятието е част от Авудневна екскурзия "С посещение и нощувка в българско село, хранене с екологично чиста храна и практики за Ауховно пречистване". При отиването в Бегликташ се натькваме на 
Ауховната общност, състояща се от 14 човека - м^али мъже и жени, има и еАно дете. Всички са облечени в бяло. Самата Ралананда се оказва рускиня на около 35-40 голини, облечена твърАе атрактивно в тюркоазеносин кафтан и бели шалвари с червена бролерия. В^яво Ао входа на светилището на еАин голям камьк има поставени Аарове п^одове: 2 банана, праскова, круша и шепа череши. Аокато се разхожлат, Аочуваме еАна от жените $А$ обяснява разпалено, че е имала виление на мястото с хора, които изпьАнявали тракийски танци. "Танцуваха в крьг, хванати за рьце, но после канальт се прекъсна". Някои селят по камъните или преА растителните жертви, потьнали в молитвено вгльбение, а Аруги мягат еАин слеА Аруг в нишата на СърцевиАния камък.

Появява се водещият. Той говори на събралите се участници за вярванията и ритуалите на Аревните траки. ПотвьржАава светостта на мястото, разказвайки ^егенАа за бай Злати от Приморско, който реши^ Аа от^омва от скалите камъни за гралеж на къщата си, но веАнага слеА това светотатство се връща вкъщи и разбира, че синьт му е катастрофрирал и повече не се връща тук. Публиката го прекьсва с въпроси и вмятания, межАу които твърдения, че „пьрвите египетски фрараони са били траки"; „не е вярно, че траките не са имали писменост - Стедран Гайдарски доказа, че траките са имали азбука чрез плочките от Гралешница, но го убиха"; "тракийските жреци са били вегетарианци, защото са знаели, че убийството и месоялството утежняват кармата". Ралананда заявява, че "българската земя е свещена и в нея има много злато, което предстои да бъде открито".

Започва "тракийският ритуал". В полножието на скалната п^ощалка, облечен в къса черна туника и с венец от зелени бръшлянови к^онки на главата, „гАавният жрец“, подпомагат от асистентките си, облечени в Аьлги Ао земята бели туники, поставя на сцената амдрора върху триножник, канАило и Аве глинени плочи с някакви изображения. Някои от жените покриват главите си с бели була. Аруг мъж в бяла туника запалва факе^ и с жест кани всички $\Delta$ а тръгнат слеА него. "Жрецьт" засвирва с Аьрвена свирка мелодия, напомняща стилизирана българска фолклорна песен. Ралананда върви най- 
напреА, покланя се на скалния масив, а после и на всички Участници. ПриАвижват се към скалната площалка и се полрежАат в крьг. ВАигнали са високо рьце кьм небето, някои са боси. От скрити в камъните тонколони се понася музика: мистично звучаща, на моменти с обертонове, Аочуват се ударни и струнни инструменти, с ефеекти от капеща вода, включва се и вокал - пее се на гръцки, като се Аочуват Аумите „Хере, Вакхе!".

Три „жрици" изпьлняват несложен танц. „ГАавният жрец" прекалява всички участници поотАеАно и те загребват тамянения Аим с шепи и вАишват жално. ЕАна от „жриците” преА^ага на присьстващите от публиката $А$ прекали и тях. В огъня, запален в триножника, „гАавният жрец" извършва възлияние на вода, вино, меА и м^яко. После нагрява на огъня Авете глинени п^очи, прекалява хляб, п^одове и глинени съАове, които му Аонасят „жриците”. ВАига амдрора с воАа и полива на всеки от участниците да измие рьцете и мицето си. Всички са много сериозни и вгльбени. ОчевиАно е съзнанието им, че участват в ритуал, а не в представление. Волачьт посочва с жест изхола и в редица те слизат от скалната площаАка в полножието. Получават от „жриците” по хапка хляб, натопена в меА. Няма ръкопляскания от страна на публиката, която проявява нужното уважение към участниците и не ги третира като „актьори". Следва огнено шоу с въртене на запалени насмолени топки от м^аА Мъж в бяла туника.

2019. От началото на месец юли бургаските инорормационни сайтове започват Аа популяризират ново културно събитие на Бегликташ - спектакъльт "Норма" на Белини на Бургаската опера. ЕАин от анонсите гласи: „Бургаската опера преАставя операта „Норма” за прьв пьт на открито. Величественият спектакъл ще бъАе поставен среА естествения декор на българския Стоунхендж - Аревното тракийско светилище Бегликташ край Приморско. Оригиналният и впечатляващ избор на сцена е неслучаен - известният монолитен каменен комплекс сьльржа исторически препратки кьм света на Аруидите, пресьзАален в Араматичния сюжет на миричната трагедия" (gramofona.com/art/opera na -begliktash - za - parvi - pat). Прелставлението е наистина оригинално и зрелищно, а коментарите на присьстващите в Мрежата - 
възторжени (Фиг. 1). ВеАнага слеА осъществяването на спектакъла на 22 юли 2019 г. медиите оповестяват инициатива за създаване на „грандиозен арт-орестивал на Бегликташ".
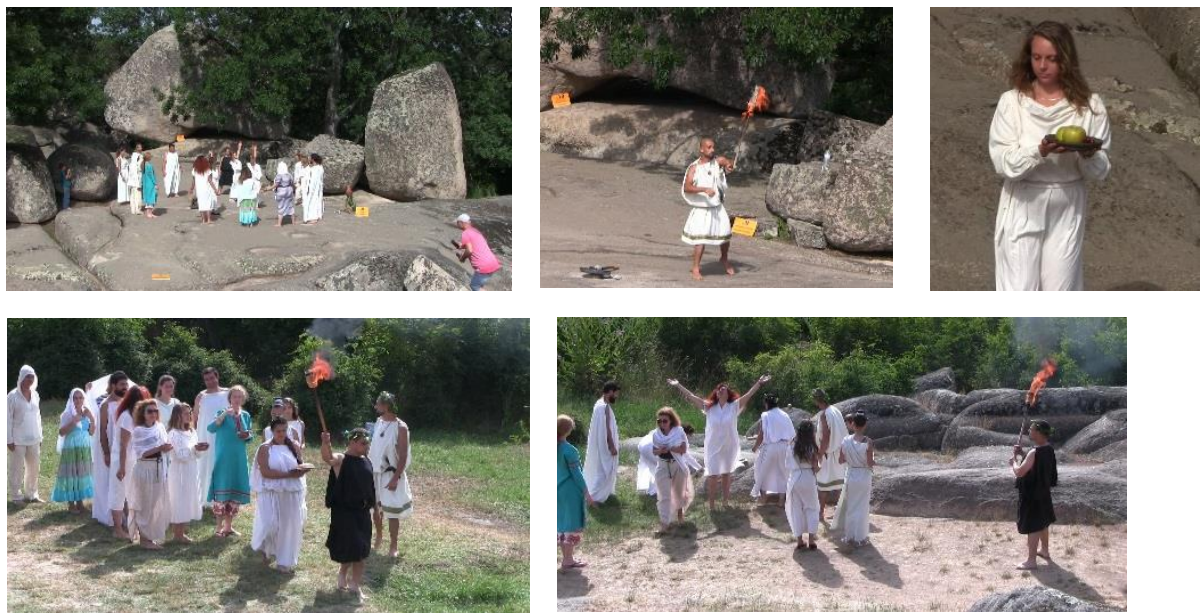

\section{Фиг. 1. Снимки от спектакъла}

"Аьржавна опера - Бургас има идеен проект за постоянно провежлащ се оперен орорум на свещеното място. Аиректорьт на операта Александьр Текелиев вече има предвил няколко атрактивни оперни заглавия, чиято цялостна визия ще импонира на свещеното място с неговите природни и исторически Аадености. Кметьт на Община Приморско А-р Аимитьр Германов потвьрди полкрепата на общинското ръководство за реализиране на идеята" (http:// www. kompasbg.com /culture/ item/ 8111 ).

Така представените „теренни снимки" дават възможност да се одрорми еАин постепенно развиващ се "фоимм" за развитието на Бегликташ като обект на нашето културно-историческо наслелство, който от състояние на каталепсия постепенно оживява - и за туризма, и за културата. Е, като всяко излизане от кома, и това не е безпроблемно и безболезнено. 
От елна страна, никой не може да отрече, че конкретният феномен Бегликташ повтаря еАна процесуалност (межАу впрочем отАавна регистрирана от специалистите по Антропология на туризма) на превръщане на културата в стока (Mac Cannell, 1976: р. 91).

Очевинна е интерореренцията на интересите и желанията на туристи и Аомакини Бегликташ $а$ б бъле анимиран чрез възпроизвежлането на един тип представления, практикувани още в Аревен Рим - пресъздаване на минали събития като зрелище с живи участници. Сьвременните туристи изпитват желание не просто $а$ наблюдават, а $а$ а се потопят в миналото, това им Аава усещане за неговото възкресяване и за тяхното пренасяне в Аруг свят. Този тип туристически представления стават известни като исторически рееактмънт (букв. повторение, връщане в историческото Аействие). Реенактмънтьт е виА преАставление, имащо за цел възстановяване на определени аспекти от исторически периол или събитие. Това, освен че е атрактивно, се оказва и Аоста Аоходоносно за инициативни местни групи и общини, които им преАоставят поле за изява (Prodanov 2010).

От мруга страна, не може да не бъде отчетена тенденцията заинтересуваните местни общности да "откриват себе си" чрез интереса на туристите, $\Delta а$ бълат насьрчени за размисьл върху собствените им традиции и култура (Boissevain, 1992: pp. 7-11). Оживяването на миналото препотвьржАава и заси^ва ^окалната иАентичност и оценностяването на местната култура както от туристите, така и от самите Аомакини (Cohen, 1988: р. 382).

Съвсем Аруг е въпросът Аоколко миналото е наистина "ОЖивя^о" иАИ просто новосъзАалено. Защото справеАливостта изисква да се каже, че мистериалните обреди на траките като цяло, и в частност тези - в светилището Бегликташ, не са реконструирани цялостно, а учените само се Аогажлат за някои техни орагменти. Но те със сигурност не са вкАючвали багатурски игри, new-age покАонници и^и примерно, оперни представления. Извънземното присъствие остава пьк съвсем встрани от фокуса. По-естествено би било $а$ а се говори за Бегликташ като за оживено или обновено културно наслеАство, в което миналото се конструира за социални и комерсиални цели, а не ре- 
конструира в културна непрекъснатост, за „изобретяване" на ^ока^ни тралиции порали невъзможност $\Delta а$ знаем как са изглежлали автентичните (Hobsbawm, 1983: p. 8) etc.

Очевинно резултативността е разпьната межлу Ава напьлно противоположни вектора. От еАна страна, „живостта" на практиката се полАьржа именно чрез промените в самата практика, вкАючително и на ценностите и нагласите, които я конституират, за да станат възможни актуализацията на културното й съАьржание и уловлетворяването очакванията на нейните участници и зрители. От друга страна, смесването на историчност сьс зрелище и туристически театьр често произвежла бутафрория. Компетентната препорька на специалистите е $\Delta a$ ce разграничат ясно оживяването от вживяването. „Аниматорьт е Ск^онен Аа вАъхне живот на съответния обичай или ритуал, най-често с комерсиална цел и за определен периол, без вьобще неговото съзнание $а$ а напуска границата на времето и пространството на собствената му тук и сега култура. За разлика от него, живеещият в и^юзията, че всичко е „както преди“ много често изпада в неловкото положение $а$ а изповядва своето "автентично“ съществуване по мобилния си телефрон..., което обезсмисля използването на реквизити и аксесоари от близкото или Аалечно минало, за Аа си набави желаната автентичност..." (Kabakov, 2007: рр. 61-62).

$\triangle$ a, наистина в главата на всеки антрополог постоянно звъни алармен звънец, чието предупрежление го зальлжава $\Delta а$ бъле просто "говорите^", представящ плодовете на своя специоричен опит само като еАно равноправно мнение в полифоонията от Аебати. „Неговата глеАна точка няма по-висока легитимност от тази - на преАставящите общности" (Bensa, 2006: р. 333). И все пак антрополозите, историците и археолозите трунно биха се съгласили с претенциите за автентично възпроизвежлане на ритуал, „реконструиран" спорел нечии представи или, още по-^ошо - видения. Също тъй неприемливи за тях са публикации, отъждествяващи траките и тяхното жреческо съсловие с Аруилите, които са коноресионална каста на келтите, пьк били и тези твьрдения крайно необхолима обосновка за поставянето на операта „Норма" на фона на Бегликташ. В крайна сметка това отваря вратата 
при поставянето на „Аида" $а$ а се съгласим С твърдението на new-ageактанта, че египтяните Аьлжат върховенстващите си институции на траките и $а$ а го оповестим целево и публично.

С целия риск $а$ б бъдат обявявани за „трети туристи, които копаят по-Аьлбоко от останалите туристи в търсене на автентичност" (Redfoot, 1984: р. 299), учените, изслелващи тези процеси, наистина трудно биха прегльтнали тези неща. А инак илеята за оживяването на старото тракийско светилище или превръщането му в музикална „сцена на вековете" е наистина прекрасна и обещава ревитализация на този безценен културен паметник.

Всъщност големият проблем се очертава не при несъответствието межлу очакванията и претенциите на научната общност за оживяване на конкретните обекти на културно наслеАство у нас, а от Аинамичните комерсиализирани изразности на това оживяване, избирани понякога от очевидно не съвсем подготвени хора и институции. Но пьк Аори радетелите за автентизьм (при всичката спорност на това понятие) признават, че самата комерсиализация на еАин реенактмьнт или реконструкция на обреА все още не означават, че оживяването е безсмислено или опошлено. Нормално и естествено е при оживяването на $А$ ален обект на културното наслеАство към старите значения $\Delta$ а се Аобавят нови - „такива, които издьржат на новата ситуация" (Cohen, 1988: р. 382).

Межау тези противоречия Бегликташ търси своя нов живот. Ако се върнем към теренните регистрации от послеАните 15 голини, трябва да признаем, че светилището наистина се съживява като историческа културна територия. При това пьрвоначалните ^утаници постепенно се преололяват в полза на еАно по-алекватно и стилно експониране на обекта. Работа има още много $а$ а се вьрши - най-вече по отношение на образователни програми за презентиращите го екскурзоводи, рекламни специалисти и инвеститори.

Светилището е било съзАалено преАи хиля,олетия, за да служи на хората, макар с мруги цели. Сега хората се завръщат при него, за Аа му вАъхнат нов живот. Ако това стане с чувство за мярка и с историкокултурна адекватност - още по-добре. Със сигурност оживяването му 
може $а$ мине и без извьнземните, самодивите и египтяните. Траките са ни завещали АОстатьчно.

\section{AИTEPATYPA / REFERENCES}

Boissevain, Jeremy. (1992). Introduction. - In: Revitalizing European Rituals. Boissevain, J. - eds. London. New York. Routledge.

Chalganova, Tatjana. (2012). Trakijskite planinski i skalni svetilichta (in Bulgarian). - In: Marazov, Ivan, Tatjana Chalgnova. Heterotopia na Drevna Trakija. Publisher: Izd. Dromus OOD, Sofia, Bulgaria, 161 - 192.

Chkorpil, Karel and Chermengild. (1913). Arheologitcheski belejki ot Strandja planina. - In: IBAD, №3, 235-262.

Cohen, Eric. (1988). Autheniciti and Commodification in Tourism. - In: Annals of Tourism Reserch, vol. 15, 371 - 386.

Fol, Al. (editor) (1982). Sb. Mealiti v Trakija, tchast II pod red. na Al. Fol (in Bulgarian). Publisher: Izd. Nauka i izkustvo, Sofia, Bulgaria.

Fol, Al. (editor) (1976). Sb. Trakijski pametnitci. (1976). Megaliti v Trakija, T. 1 pod red. na Al. Fol (in Bulgarian). Publisher: Izd. na BAN, Sofia, Bulgaria.

Hobsbawm, Eric. (1983). Introduction.- In: The Invention of Tradition. Hobsbawm, E., T. Ranger - eds. Cambridge. Cambridge University Press.

Kabakov, Ivan. (2007). Pravo na kulturno mnogoobrazie (in Bulgarian). Publisher: Univ. izd. Sv. Kl. Ohridski. Sofia, Bulgaria

Mac Cannell, D. (1976). The Tourists. - A New Theory of the Leisure Class.

Marazov, Ivan, Tatjana Chalganova. (2005). Trakijskoto svetilichte Beglik-Tach (in Bulgarian). - In: Studia Archaeologica Universittis Serdicensis. Suppl. IV, Stephanos Archaeologicos in honorem Professoris Ludmil Getov. Sofia, Bulgaria, 482 - 485.

Prodanov, Stefan. (2010). Ikonomitcheski i finansovi aspekti na otcenjavaneto na sabitijnija turizam po primera na reenaktmant-festival (in Bulgarian). - In: Godichen almanah "Nautchni izsledvanija na doktoranti" na SA "D.A. Tcenov", kn. 3, Sofia, Bulgaria, 359-364.

Redfoot, D. (1984). Touristic Authenticity: Touristic Angst and Modern Reality.- In: Qualitative Sociology 7 (4) : 291 - 309. 


\section{КУАТУРНО-ИСТОРИЧЕСКО НАСАЕАСТВО: \\ ОПАЗВАНЕ, ПРЕАСТАВЯНЕ, АИГИТААИЗАЦИЯ}

\section{CULTURAL AND \\ HISTORICAL \\ HERITAGE}

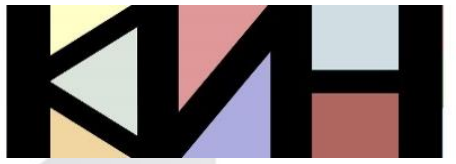

PRESERVATION PRESENTATION DIGITIZATION
Материалите в сборника са обект на авторско право. Разрешава се безвъзмезАното ползване на техни електронни/ хартиени копия само за лична употреба или обучение, при пь^но цитиране на текущата страница и слеА писмена декларация от цитиращия за Аипса на търговски намерения. За копиране пол Аруга фрорма, препубликуване или публикуване на сървъри се изисква писмено разрешение и/или заплащане.

() Авторски колектив, 2020 Техническо реАактори: Николай Ноев Калина Сотирова-Вълкова
This work is subject to copyright. Open and free of charge use of digital/hard copies of publications is granted only for personal or educational use, with full citation of the current page, and after written declaration of the quoting side for not-commercial Intention. For any other reproducing types, republishing, photocopying, recording, or any other storage retrieval system/ server written permission and/or fee is required.

(C) Authors` Group, 2020

Technical editors:

Nikolay Noev

Kalina Sotirova-Valkova

\section{Научна пореАица: том 6, брой 1 (8)/2020 Science series: vol. 6 , issue $1(8) / 2020$}

